\title{
Misiunea parohială în rândul tinerilor în Biserica Ortodoxă Finlandeză
}

\section{Vlad TOADER}

Abstract: Having basically always lived together with the other national church of Finland, the Lutheran Church, which represents the majority, Orthodoxy in this northern country developed certain traits that make it certainly different from other local Orthodox churches. The church does a complex mission among its members, structured on age groups, e.g. children and youth. Mission strategy shares from the Lutheran majority's experience as well. A characteristic of the Finnish Orthodox Church is the relatively large number of organizations, brotherhoods and societies that function in it, so that parish mission for children and youth is done both through the own means of the parish and through the help of certain organizations orientated on mission work.

Keywords: inner mission, parish mission, Christian camps, church organizations.

\section{Contextualizare și devenire}

Minoritate într-o mare de protestantism luteran, ortodoxia este cea care a păstrat până astăzi pentru poporul finlandez, alături 
de Tradiţia sacră multimilenară a creștinismului ortodox, și tradiţiile populare și memoria devenirii acestui neam din nordul îndepărtat. Elias Lönnrot este poetul, filologul și cărturarul finlandez care a întocmit vasta culegere de poeme folclorice Kalevala, mitul fundamental al acestei națiuni. Spațiul din care Lönnrot a cules Kalevala este tocmai Karelia ortodoxă ${ }^{1}$. Privind la diversitatea uimitoare de formă, culoare şi poezie a portului popular românesc, vedem că astăzi în Finlanda nu mai supraviețuiește şi nu mai este folosit decât un singur fel de astfel de port, anume cel karelian. Deși luteranismul finlandez nu a cunoscut manifestări iconoclaste, iar arta bisericească medievală romano-catolică a supraviețuit în bisericile vechi devenite luterane ${ }^{2}$, totuşi puritanismul protestant a distrus manifestările artei populare ale acestei nații, artă cu valențe identitare.

Vedem deci că şi în acest caz, ca şi în al majorității celorlalte biserici ortodoxe, Ortodoxia a absorbit precum un burete identitatea neamului care a îmbrățișat-o, păstrând-o și conservând-o peste veacuri. Dacă însă în cazul sârbilor, sau al grecilor, sau al rușilor sau al nostru înșine, Biserica Ortodoxă a fost și cea a națiunii însăși, alta a fost și este situația, așa cum am văzut, pentru ortodocșii finlandezi. Mereu minoritari, mai întâi printre ortodocșii Imperiului Țarist și locuitorii Marelui Ducat al Finlandei ${ }^{3}$, apoi printre cetățenii Republicii Finlanda, aceștia au trebuit să găsească mereu soluții pentru a nu se pierde precum o picătură de apă în marea unei majorităti diferite de ei. Au existat însă oameni providențiali în istoria Bisericii Ortodoxe Finlandeze care au găsit aceste soluții ${ }^{4}$.

${ }^{1}$ Lönnrot, Elias, Kalevala, București, Edit. de Stat pentru Literatură și Artă, 1959, Introducere, p. II.

${ }^{2}$ Ken Parry et al., The Blackwell Dictionary of Eastern Christianity, Oxford, Blackwell Publishing Ltd, 2004, p. 200.

${ }^{3}$ Iida Katarina Hirvasaho, A Stepchild of the Empire: Finland in Russian Colonial Discourse, Los Angeles, University of California, 1997, p. 18.

${ }^{4}$ Teuvo Laitila, From a Russian Guberniya to a Part of Finland: The Legislative Position of the Orthodox Church and People in the Grand Duchy of Finland in 


\section{La nivel organizațional}

Trauma celui de al Doilea Război Mondial nu a lăsat neafectată nici tânăra și plăpânda încă Biserică Ortodoxă a Finlandei. Răfuiala cu Uniunea Sovietică a jupuit Finlanda de teritorii. Deși populația a fost salvată de ciuma sovietică, majoritatea oamenilor fiind evacuați, aceștia s-au împrăștiat pe o suprafață vastă, luterană. În toiul acestui iureș al istoriei a luat naștere Ortodoksinen Nuorten Liitto (Asociația Tineretului Ortodox sau $O N L$ ), fondată în anul 1943, la Sortavala, capitala de suflet a Kareliei, aflată azi în Rusia, de către profesorul de limbă finlandeză Pentti Härkönen și de alți clerici și laici. Aceștia au dorit să asigure noilor generații conștiinţa identităţii ortodoxe.

În Finlanda taberele sunt modul principal în care se organizează predarea de învățături de credință și unde se organizează educația în spirit creștin a copiilor și tinerilor de către Bisericắs. Metoda a fost folosită de către ONL de la începutul existenței sale. În anii ' 50 această asociație organiza taberele în locuri precum Puroniemi și Keitele, la care participau peste o sută de copii de care aveau grijă un singur preot și soția sa. Părintele îi învăța pe copii iar preoteasa gătea pentru acest grup enorm de persoane ${ }^{6}$. Ajungând în prezent, misiunea parohiilor în rândul membrilor săi copii și tineri este organizată printr-o colaborare între ONL și diversele parohii, colaborare ce poate lua forme diferite în funcție de caracteristicile și nevoile specifice ale fiecărei unități teritoriale bisericești în parte.

De la începuturile sale, misiunea ONL a fost de a organiza taberele pentru copii și tineri, de a publica revista Tuohustuli (Lumina candelei), începută din $1953^{7}$, cât și a materialelor necesare care să sprijine catehizarea acestora, și de a organiza sărbători ale tineretului la

the Nineteenth Century, în „CHRONOS”, Revue d'Histoire de l'Úniversité de Balamand, Tripoli, 2010, p. 23.

${ }^{5}$ Cf. interviului cu Pr. Teemu Toivonen, 23.03.2015.

${ }^{6} \mathrm{Cf}$. Interviului cu Jasso Pössi și Annakaisa Leussu din 13.03.2015.

${ }^{7} \mathrm{Cf}$. https://www.ort.fi/hakemisto/tuohustuli, accesat pe 03.07.2015 
o anumită perioadă de timp. Astăzi ONL și-a restrâns mult activitatea de organizare a taberelor, lăsând-o în seama parohiilor, pentru încuraja astfel relaţii cât mai frecvente între acestea și membrii lor. Încă se mai organizează un singur rând de tabere pe an, în scopul de a ajuta parohiile mici ce nu pot organiza astfel de acțiuni ele însele. Taberele sunt de mai multe feluri. Cea mai însemnată categorie sunt acele kristinoppileiri, tabere de învățătură de credință creștină. Ele sunt o adevărată instituție în Finlanda și au fost preluate acum mai bine de o sută de ani ${ }^{8}$ din practica Bisericii Luterane majoritare, unde în cadrul lor are loc și confirmațiunea. Kristinoppileiri este atât de împământenită în această cultură, încât este organizată și de așa-numitele Biserici Libere (facțiuni ale Bisericii Luterane), de penticostali, și chiar de Asociația Prometeus pentru tinerii nemembrii ai niciunei biserici. Astfel se organizează și taberele Prometeus pentru liber-cugetători ${ }^{9}$. În cadrul acestora se predau în general noțiuni de etică.

Desigur, în Biserica Ortodoxă nu există Confirmațiunea, însă tabăra se organizează căpătând caracteristici proprii. Durează între șapte și zece zile, adresându-se doar tinerilor ce pe parcursul anului respectiv împlinesc vârsta de 15 ani. Programul conţine slujbe zilnice în fiecare dimineaţă și seară, adică utrenia, vecernia și câteva liturghii. Atunci când se slujește Sf. Liturghie, toți sau aproape toți se împărtăşesc, pentru că în Finlanda se accentuează scopul singur al liturghiei ca fiind spre primirea Euharistiei de către toți, ca în cuvântul de instituire al lui Hristos de altfel, spre deosebire de realitatea din România, unde aceasta se dă pruncilor şi poate unuia sau maxim câtorva credincioși ca premiu de merit.

Activitățile se desfășoară atât cu toți participanţii cât și pe grupuri mai mici. Catehezele sunt o altă parte importantă a acestor tabere la care participă toți tinerii. Se predau teme ca: Cine este Dumnezeu,

\footnotetext{
${ }^{8} \mathrm{Cf}$. interviului cu Pr. Teemu Toivonen, 23.03.2015.

${ }^{9} \mathrm{Cf}$. interviului cu Excelenţa Sa Doamna Ulla Väistö, Ambasadorul Finlandei la București, 05.05.2015.
} 
Dumnezeu Creatorul, Ce este omul, Iisus Hristos, Biserica, Biblia, Sf. Taine, elemente de etică, Ortodoxia în Finlanda și peste hotare, etica sexualității și căsătoria. Catehezele sunt ținute de un preot și de teologul taberei, de regulă un student teolog special plătit pentru aceasta. Au loc și activități: astfel tinerii învață să coacă prescuri, să-și găsească sfinții ocrotitori și să le citească viețile, să realizeze icoane, sunt implicați în activități gospodărești precum curățenia în biserică, culegerea fructelor de pădure din care pregătesc conserve pentru iarnă. Mai există grup de cântare și altul de citit la strană. Fiecare copil parcurge toate activitățile organizate în cadrul taberei ${ }^{10}$. Se mai organizează și diferite jocuri rezervându-se și timp liber.

Un alt element important și inedit îl reprezintă explicarea prin cuvânt și mai ales exemplificare cu ajutorul voluntarilor din rândul participanților, a slujbelor importante din viața unui creștin: botez, nuntă, maslu, înmormântare. Din mărturia părintelui Teemu Toivonen, președinte al ONL și preot de parohie al Parohiei Helsinki, însărcinat cu activitățile educaționale, se pare că în fiecare tabără rolul mortului este cel mai disputat între participanți ${ }^{11}$.

Într-o tabără de învăţătură de credință creștină organizată de ONL participă treizeci de copii și încă 13-14 persoane angajate între care liderul taberei, teolog, un cântăreț bisericesc, consilieri (peste 18 ani) și lideri de grup (15-16 ani), de obicei tineri care au fost în kristinoppileiri proprie în anul precedent, și un preot. ONL organizează taberele la centrul Puroniemi.

Grupurile conțin în general 6-7 persoane și sunt conduse de un lider de grup. Un loc pentru un copil de 15 ani într-o astfel de tabără organizată de ONL costă 325 de euro. Copii plătesc prețul integral, o parte din preț, sau acesta este în întregime este acoperit de parohie. Parohiile mari dețin propriile locații pentru organizarea de tabere, ca de exemplu Helsinki, Joensuu, Jyväskylä, altele pot închiria astfel

\footnotetext{
${ }^{10} \mathrm{Cf}$. interviului cu Pr. Teemu Toivonen, 23.03.2015.

${ }^{11}$ Idem.
} 
de complexe. Taberele sunt organizate ținând cont și de numărul de solicitări: la Helsinki se organizează 6-8 tabere pe an, la Joensuu 3, ONL organizând una singură.

În conexiune cu taberele de învățătură de credință ortodoxă, ONL organizează și cursuri pentru consilieri de tabere și lideri de grup. Acestea se prezintă sub forma a două cursuri: cel pentru începători și cel de continuare. Un curs se desfășoară pe perioada unui sfârșit de săptămână, de vineri până duminică. În cadrul lui sunt predate noțiuni despre rolul consilierului, cum sunt organizate jocurile etc. Din perspectiva ONL, cursul de începători este util pentru cunoașterea personală a posibililor viitori candidați și deci, în momentul în care aceștia aplică, nu sunt un nume pe o hârtie sau pe un ecran, ci fețe cunoscute. Primul curs are loc de obicei în luna martie. În luna mai cei care au fost selectați pentru a lucra în tabere fac cursul avansat unde sunt învățtați lucruri practice: prim ajutor, prevenirea incendiilor, cum să încălzească sauna etc. Categoria de vârstă a candidaților este în general între 15 și 18 ani.

Diferitele parohii au posibilitatea de a pregăti astfel de consilieri şi lideri cu ajutorul ONL sau își pot organiza propriile cursuri. Tot la cerere ONL poate recomanda consilieri de tabără pentru diferitele nevoi întâlnite în parohii. Pentru fiecare curs de pregătire se plătește o taxă de 35 de euro de cursant. Anul în curs, 2015, a fost unul în care interesul pentru aceste cursuri a fost unul semnificativ după cum relatează diaconul Jaso Pössi și Anna Kaisa Leussu, angajați permanenți la sediul ONL, la evenimentele ținute la Pieksamäki participând 54 de persoane.

O altă activitate întreprinsă atât de ONL cât și de parohiile ortodoxe finlandeze o reprezintă organizarea taberelor pentru copii. Acestea sunt destinate copiilor cu vârste între 7-14 ani durând de obicei patru zile. În program sunt cuprinse slujbe zilnice și cel puțin o liturghie, mai puține activități catehetice și mai mult timp liber și jocuri, fără a se uita însă de contextul ortodox în care se desfăşoară. 
Pentru un loc într-o tabără organizată de ONL părinții plătesc 60 de euro, putând plăti și 30 de euro dacă se înscriu prin parohii.

Tuohustuli (Lumina candelei) este revista destinată copiilor, tinerilor și părinților. Apare de patru ori pe an în 4300 de exemplare. Parohiile sunt principalii abonați, dar există și abonați individuali. Sunt parohii care comandă revista pentru o anumită grupă de vârstă din parohie, altele comandă pentru toți copii. Revistele sunt livrate gratuit la domiciliul familiei copilului. În ea se publică interviuri, benzi desenate despre viața lui Patee - motanul unei familii ortodoxe, articole de hobby, etc. Doamna Jaana Pössi, fost președinte al ONL între 1990-2002'2, comentează că, din păcate, pentru majoritatea copiilor, singura legătură pe care aceștia o au cu Biserica, este profesorul de religie și revista Tuohustuli ${ }^{13}$.

ONL se ocupă și cu publicarea diferitelor materiale precum cărticele de rugăciuni, manual pentru altar, pentru paracliseri, cu ilustrații, traduceri etc. O lucrare scurtă dar foarte cuprinzătoare, care a fost publicată în finlandeză și tradusă până acum în engleză, rusă, suedeză, careliană, laponă skolt și swahili, este Ce, De ce, Cum, în Biserica Ortodoxă. Astfel, organizația se constituie într-o resursă pentru activitățile cu tineretul ale Bisericii Ortodoxe. Aceasta participă şi la organizarea de tabere pentru adulți și familiii ${ }^{14}$.

Finanțele asociației provin din partea Bisericii în cea mai mare măsură, de la stat prin subvenționarea activităților pentru tineri, din prețul biletelor vândute în tabere și abonamentele la revista Tuohustuli.

Pentru a concluziona, putem afirma că ONL organizează activitatea cu tineretul ortodox finlandez la nivel naţional și de asemenea, într-o măsură și la nivel internațional, fiind implicată în activitățile Syndesmos, organizație internațională a tineretului

\footnotetext{
${ }^{12} \mathrm{Cf}$. interviului cu Jaana Pössi din 12.03.2015.

${ }^{13}$ În Finlanda, Religia este materie obligatorie de studiu și se predă începând de la grădiniță și până în ultima clasă de liceu.

${ }^{14} \mathrm{Cf}$. interviului cu Jaana Pössi din 12.03.2015.
} 
ortodox, încă de la începutul existenței acesteia.

\section{La nivel parohial}

Pentru a avea o imagine mai clară a activităților cu tinerii, au fost culese in formații legate de problema misiunii parohiale în rândul tinerilor în cadrul parohiei celei mai vaste ca întindere și celei mai numeroase din punct de vedere al numărului membrilor, parohia ortodoxă Helsinki. Date fiind cele mentionate, în cadrul acestei parohii se organizează și activitatea cea mai bogată și variată. Sursa informaților a fost părintele Teemu Toivonen, preotul însărcinat, cu activităţile educaţionale ale parohiei, și președintele actual al ONL. Acesta activează ca lucrător cu tineretul din anul 2005 ${ }^{15}$.

Administrația parohială are o echipă dedicată activităților educaționale, alcătuită din șapte membri: managerul echipei, însărcinat cu finanțele și resursele umane, cântărețul bisericesc pentru tineret, un lucrător pentru copii, unul pentru tineri, unul pentru familii și unul pentru educaţia adulților și educaţia religioasă în școli. La aceștia se adaugă preotul responsabil cu activitățile educaţionale.

În Helsinki aflăm că 60-70\% din tinerii de 15 ani participă la taberele de învățătură creștină. Ele au loc de vineri până vineri, în complexul special destinat acestora, încheindu-se sâmbăta cu Sf. Liturghie, oficiată special într-una dintre bisericile Uspenski, Tapiola sau Tikkurila. Pentru anul 2015 sunt programate șapte astfel de evenimente, din luna iulie până în august. Pe lângă toate lucrurile menționate mai sus, se adaugă și faptul că majoritatea covârşitoare a participanților cu acest prilej se și spovedesc, de multe ori fiind prima și singura dată când o fac ${ }^{16}$.

Parohia deține un complex pentru tabere la Kaunisniemi, prețul

\footnotetext{
${ }^{15} \mathrm{Cf}$. interviului cu Pr. Teemu Toivonen, 23.03.2015. ${ }^{16}$ Idem.
} 
pentru un participant fiind de 150 de euro. Deoarece de obicei se depășește capacitatea acestui loc, se organizează kristinoppileiri și în Estonia, un loc costând 250 de euro, din cauza programului mai complex, acesta conținând și o excursie la Mânăstirea Petseri.

Dacă familia copilului nu posedă resursele financiare pentru a plăti prețul biletului, atunci parohia apelează mai întâi la serviciile de asistență socială. În Finlanda acestea acoperă și cheltuieli pentru hobby-uri pentru copii. În urma anchetei realizate, aceste servicii pot acoperi total sau parțial costul. Diferența rămasă, de la o fracțiune până la $100 \%$, dacă Asistența socială nu a plătit nimic, este dată de parohie. Vedem deci că este nevoie doar de un exercițiu de voință din partea copilului și a părinților lui spre aceasta, pentru ca Biserica și Statul să vină în întâmpinarea credinciosului, respectiv a cetățeanului, dintr-o grijă autentică pentru e ${ }^{17}$.

În kristinoppileiri la Kaunisniemi participă maxim 36 de tineri într-o serie, iar în Estonia maxim 24. Numărul nu se mărește în mod intenționat și părintele Toivonen furnizează și explicația: „Cel mai important este că se formează un grup și ei ajung să se cunoască unul cu altul. Noi suntem o minoritate, iar copii ortodocși sunt probabil unul sau doi în școala lor. Așa ajung să se cunoască între ei, să vadă că nu sunt singuri, și noi ajungem să îi cunoaștem la rândul nostru"18.

Fiind un adevărat ritual de trecere, încheierea taberei de învățătură de credință creștină se face în mod festiv cu o Sf. Liturghie şi apoi un eveniment de socializare la care participă familia extinsă a tânărului, prieteni etc.

Pentru copiii între 7 și 14 ani în parohia Helsinki se organizează 4 tabere pe an, toate la Kaunisniemi, cu durata de 4 zile, pentru 25 de euro pe zi, deci un total de 100 de euro. Se acordă reduceri pentru mai mulți copii din aceeași familie. Se organizează jocuri, pe grupuri mici se fac și discuții legate de Biblie sau Biserică, au posibilitatea de

\footnotetext{
${ }^{17}$ Idem.

${ }^{18}$ Idem.
} 
a se spovedi, participă la slujbe de două ori pe zi şi primesc Sfânta Împărtășanie în cadrul unei liturghii.

Indirect, copii și tinerii sunt implicaţi și în taberele dedicate familiilor, organizate tot la Kaunisniemi, cu prilejul unor praznice mari, ca tabăra de Înalțare, ce durează din joia sărbătorii până duminica următoare, sau tabăra de Paști, din Joia Mare până în Duminica Învierii Domnului. De multe ori participanţii sunt persoane care au fost în kristinoppileiri la Kaunisniemi și mai apoi revin aducânduși soția/soțul și copii. Prețul este calculat tot la 25 de euro pe zi pe persoană, la care se aplică reduceri de familie și de număr de persoane.

Alte tabere pentru tineri se mai organizează iarna în weekenduri pentru cei care au fost în anul respectiv în kristinoppileiri şi tabăra de Sf. Iacov, ruda Domnului, hramul paraclisului de la Kaunisniemi, când participă circa 100 de tineri.

Parohia ortodoxă Helsinki organizează și propriile ei cursuri pentru consilieri de tabere și lideri de grup, predarea realizându-se în patru întâlniri la sediul administraţiei parohiale, și într-un weekend la Kaunisniemi.

Misiunea în rândul tinerilor se realizează la Helsinki şi prin cluburile pentru copii și tineret. Cele pentru tineret se întâlnesc în fiecare zi de marți, la sediul parohiei sau în sala socială a bisericilor, la Helsinki, Espoo, Vantaa, Nummela ${ }^{19}$ etc. Încep de la ora șase, după vecernie și cuprind, în funcție de an și de loc, între 10 și 50 de tineri, de regulă între 15 și 20 de ani. Cel mai frecvent, la club participă și un preot, care încearcă, printre altele, să îi determine pe participanți să vină și la vecernie.

La Helsinki există și clubul băieților de altar, a micilor paracliseri. Pentru a ajuta în Sf. Altar, băieții trebuie să se înscrie în acest club, să participe la prelegerile ținute de tineri sub supravegherea cărora mai apoi vor participa la ajutorul în altar în timpul Sf. Liturghii. Tinerii

\footnotetext{
${ }^{19}$ Parohia ortodoxă Helsinki cuprinde mai multe orașe și sate, precum cele enumerate.
} 
care se ocupă de acest club primesc mici sume de bani ca răsplată din partea parohiei. Ei sunt obligați să lucreze în ture, pentru a implica un număr cât mai mare de persoane în viaţa Bisericii.

În fine, cântărețul bisericesc pentru tineret, ce are în grijă corul de copii și corul de tineret, se implică inclusiv în organizarea taberelor. În decembrie 2015, corul de tineret al Parohiei Helsinki va efectua un pelerinaj în Moldova ${ }^{20}$.

\section{Concluzii}

Biserica Ortodoxă Finlandeză este o Biserică Ortodoxă mică şi minoritară în acelaşi timp. Netrecând printr-o perioadă de regim statal ateu militant ca multe dintre celelalte biserici ortodoxe, totuşi a cunoscut momente de grea încercare în existența sa. Dar istoria ei este cea a poporului din care face parte și trăsăturile firii acestei națiuni nordice pot fi regăsite și între caracteristicile Bisericii. Una dintre acestea este onestitatea și deschiderea la tot ce este bun în esență, chiar dacă vine din afara sa. Așa s-a ajuns la folosirea taberelor drept cadrul principal de desfășurare a misiunii în rândul tinerilor membri ai săi, o metodă croită pe firea acestora, dar folosită la maxim pentru atingerea scopurilor urmărite de pastorație și misiune. Bineînțeles că atunci când avem de-a face cu o instituție mai veche, sau mai mare, sau mai cu greutate, schimbarea este mai lentă și chiar văzută uneori ca pe un fapt amenințător. Dar trebuie să realizăm că dacă o Biserică Ortodoxă locală a luat cu succes forme exterioare și le-a umplut cu fond total ortodox, cu atât mai ușor sunt de preluat rețete de succes ale altor Biserici Ortodoxe surori și de adaptat contextului, sensibilităţii și specificului propriu.

${ }^{20}$ Idem. 


\section{Bibliografie}

1. Hirvasaho, Iida Katarina, A Stepchild of the Empire: Finland in Russian Colonial Discourse, Los Angeles, University of California, 1997.

2. Jutikkala, Eino - Pirinen, Kaoko, A History of Finland, translated by Paul Sjöblom, Helsinki, Edit. Werner Söderström Osakeyhtiö, 2003.

3. Laitila, Teuvo, From a Russian Guberniya to a Part of Finland: The Legislative Position of the Orthodox Church and People in the Grand Duchy of Finland in the Nineteenth Century, în „CHRONOS”, Revue d'Histoire de l'Úniversité de Balamand, Tripoli, 2010.

4. Lönnrot, Elias, Kalevala, București, Edit. de Stat pentru Literatură și Artă, 1959.

5. Parry et al., Ken, The Blackwell Dictionary of Eastern Christianity, Oxford, Blackwell Publishing Ltd, 2004.

\section{Interviuri}

6. Jaana Pössi, 12.03.2015

7. Diac. Jaso Pössi și Annakaisa Leussu, 13.03.2015

8. Pr. Teemu Toivonen, 23.03.2015

9. Excelența Sa, Ulla Väistö, Ambasadorul Finlandei la București, 05.05 .2015

Interviurile se află în posesia autorului prezentului articol.

\section{Situri internet}

https://www.ort.fi/hakemisto/tuohustuli, accesat pe 03.07.2015 